Collection: RegioResources21 - "Spatial information and participation of socio-ecological systems: experiences, tools and lessons learned for land-use planning" Guest Editors: Daniele La Rosa, Carsten Lorz, Hannes Jochen König, Christine Fürst

\section{Communicating spatial planning decisions at the landscape and farm level with landscape visualization}

\section{Bartlett Warren-Kretzschmar, Christina Von Haaren}

Landscape visualizations have the potential to support participatory environmental planning at different spatial scales and decision levels from international to farm level. However, it is yet unclear what specific demands are relevant for visualization on the different decision levels. In this context more knowledge is needed about visualization objectives and the respective tasks, intended effects and suitable techniques for the specific levels. Especially the farm level has been neglected in research, although farmers make many decisions that affects public interests in the visual landscape. Farmers need to communicate these decisions to the public in an understandable way. The question of how visualization can support participation in the planning process at the municipal level is examined by drawing on the findings of the Interactive Landscape Plan Koenigslutter, Germany (IALP) about the preferences and reactions of citizens to visualizations used in the landscape planning process at the local decision level. On this basis, we examined the applicability and differences of the findings for the farm level. Furthermore, in order to explore visualization opportunities at the farm scale, the farm management system MANUELA was used as an example of an information platform that could serve as a basis for farm scale visualizations. By transferring landscape planning results to the farm level, we developed recommentations about the application of visualization, intended effects and appropriate techniques at the farm scale. The general findings for the municipal level show that visualization can improve participation by providing participants with a common image of the planning proposals for discussion and collaborative decisions. Different visualization methods offer different capabilities for supporting participation in the different planning phases. At the farm scale, 2D visualizations and diagrams are often sufficient to communicate information to customers about farm performance for providing ecosystem services. They may consist of maps and supporting information that is easily generated from GIS data. However, for a higher (more interactive) level of communication and participation activities, such as discussions with affected neighbors about land use changes or the integration of citizens' proposals, more sophisticated visualization techniques would be required. Visualization techniques are needed that farmers can use to easily simulate visual impacts of land use changes at the landscape scale.

Keywords: Landscape Planning, Participatory Planning, Landscape Visualization, Farm Scale, Ecosystem Services, MANUELA

\section{Introduction}

Visualizations are major means of communicating ecological information to the public and stakeholders. Much research has been done about visualization techniques and their effect on addressees. Landscape visualizations have been used successfully to communicate landscape issues and discuss planning decisions with experts, stakeholders and the general public (Sheppard 2005, von Haaren et al. 2005, Lewis \& Sheppard 2006, Schroth et al. 2006). Although skep- tics warn of the danger of manipulation and the over emphasis of the visual landscape (DiBiase et al. 1992, Sheppard 2001, Nicholson-Cole 2005, Soliva \& Hunziker 2009), landscape visualizations have proven to be effective in participatory planning at many different planning scales (see Pettit et al. 2012 for an overview). Certainly, landscape visualizations have limitations; however they present a common image which stimulates opinions and helps participants to formulate and question their own opinions $\square$ Institute of Environmental Planning, Leibniz University Hannover, Herrenhäuser Str. 2, D-30419 Hannover (Germany)

(a) Bartlett Warren-Kretzschmar (barty.warren@usu.edu)

Received: Oct 31, 2013 - Accepted: Apr 05, 2014

Citation: Warren-Kretzschmar B, Von Haaren C, 2014. Communicating spatial planning decisions at the landscape and farm level with landscape visualization. iForest 7: 434-442 [online 2014-05-19] URL: http://www.sisef.it/iforest/contents/? id=ifor $1175-007$

Communicated by: Marco Borghetti

(Meitner et al. 2005). Nonetheless, very little is known on how to choose the right visualization type according to the application purpose and the level of political decision in environmental issues. Decisions that require participation are not only made on the political or administrative level but also on the farm scale, where many decisions have an impact on the visual landscape and therefore effect the wider public. For example, planning farm infrastructure, such as windmills, solar panels, buildings for livestock, or farm roads, may impact the visual landscape which is enjoyed by the public. Even the conversion of grassland into agricultural fields or changes in the cropping systems from short to tall crops, such as maize to short rotation coppice, are relevant for people on a supra farm level. Furthermore, neighbors, farm customers (e.g., food companies, tourists, customers of farm sale), and authorities that decide about agri-environmental funding now require more information about farm performance and respective ecosystem services (ESS - von Haaren et al. 2012). Many of these new communication and participation tasks on the farm level can be supported by visualization.

Visualization methods offer many different capabilities and choices for presenting landscape information. The landscape can be portrayed in two, three or four dimensions or visualized with varying degrees of realism (Lange 2001, Bishop \& Lange 2005). The image may be static or dynamic and provide different levels of interactivity (Schroth 2010). Also the scale in which the landscape is visualized emphasizes different aspects and issues of the landscape (Meitner et al. $2005)$. Even the style of the visualization (i.e., stylized or realistic/detailed) influences how it can be used in planning decisions (Schroth et al. 2006). Furthermore, the choice of visualization methods is influenced by contextual factors such as data availability 


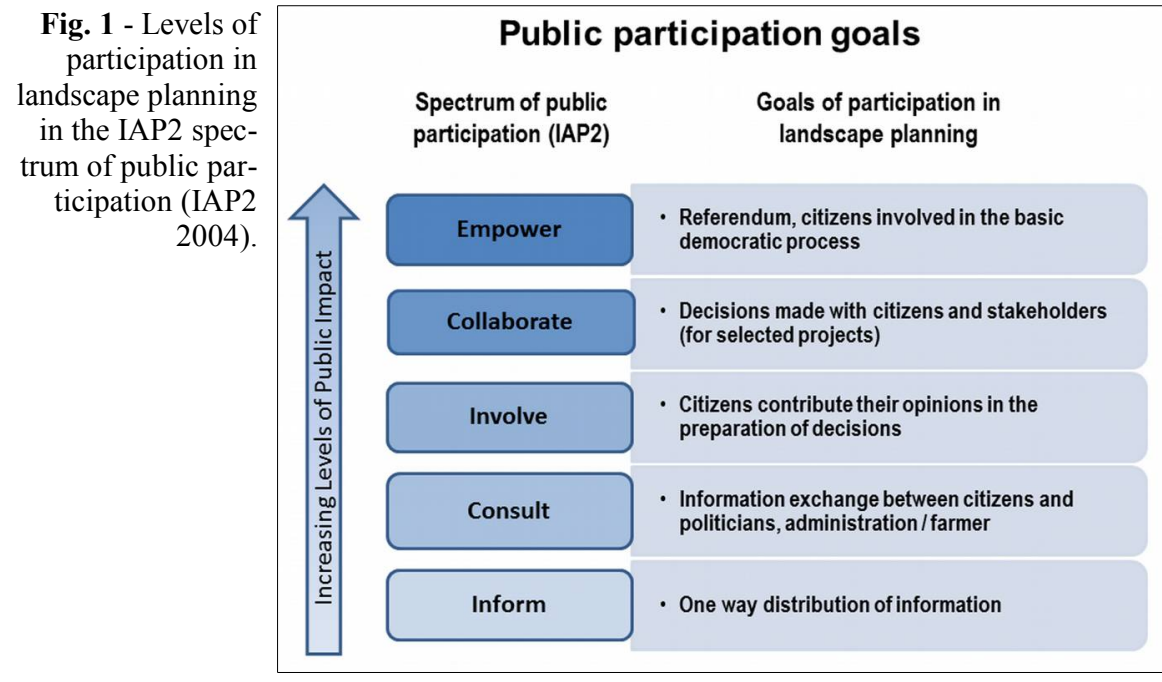

and quality, audience, size of planning area, planning issues, and the phase of the planning process (Warren-Kretzschmar 2011). In addition, the various scales of the planning decisions (global, national, state, regional, local, site) hold different questions and thus require different visualization tools (Shaw et al. 2009).

Despite the promise that visualization holds for supporting participation and the many technical options that are available, a systematic overview of the relevant requirements for visualization on the different decision levels is missing. In order to choose a suitable visualization type and technique, we need to know more about the purpose, respective tasks and intended effects visualization must fulfill on the different planning levels. In addition, research has not addressed participation and visualization on the farm level, although farmers make many decisions that affect public interests in the visual landscape.

\section{Investigation objectives and approach}

In this paper we examine how visualization can support communication with participants in the planning process, and we propose a framework for selecting appropriate types of visualization for participatory planning. Two levels of planning information are considered: the municipality or landscape scale, in which landscape planning decisions are made, and the farm scale.

Our findings on the landscape scale are based on research carried out in the research and development project, Interactive Landscape Plan (IALP) in Königslutter am Elm, Germany. The IALP was sponsored by the Federal Agency for Nature Conservation and implemented from 2002 until 2005. In the case study, data was gathered using participant observation, interviews, and quasi-experimental tests about a range of visualization techniques in different participatory set- tings, planning phases and with different application objectives. On the farm scale, an analysis of farm scale planning applications formed the basis for determining the visualization's application objectives (von Haaren et al. 2012). Using the application framework developed for the municipal decision level, we generated recommendations about the visualization type and technique suitable for the farm scale by identifying transferability and similarities. As a standard for the current technical information and visualization at the farm scale, we used the (farm) Management System Nature Conservation for a Sustainable Agriculture (MANUELA). It was initially sponsored by the Federal Foundation for the Environment (DBU) from 2005-2008 and continues to be developed at the Institute for Environmental Planning at Leibniz University Hannover, Germany.

In the following chapters we first describe the different degrees of participation and their objectives in the planning process. This is followed by a review of the different tasks and effects of visualization techniques in the planning process at the municipal level, and recommendations are made about their potential to support participation in the different planning phases. Next, different opportunities to use visualization on the farm level are identified and matched with the potential tasks and effects that visualizations can support. Finally, suitable visualization techniques are recommended for the farm level and suggestions are made about their further development.

\section{Participation in planning at the landscape scale}

Levels of participation in the planning and decision process were first characterized by Arnstein (1969) who identified eight levels of participation that range from non-participation up to citizen empowerment. Since then other researchers have revised and adapted the framework (Wiedemann \& Femers 1993, Luyet et al. 2012) For example, the International Association for Public Participation (IAP2 2004) has adapted the Arnstein's categories into different levels of communication and public impact: information, consultation, involvement, collaboration and empowerment (see Fig. 1). In all frameworks, the objective is to move from the one-way information delivery to the involvement of the public in decisions and democratic legislation. However, when the benefits promised from participation are not realized, planners and stakeholders often become disillusioned with the process (Reed 2008). The discrepancy that may exist between the actual and perceived participation is called the "Arnstine gap" (Bailey \& Grossardt 2009). It is argued here that visualization can help to close the Arnstine gap by improving participants' understanding of the issues and their ability to communicate their knowledge and ideas at all levels. Visualization may not only improve people's understanding of the planning issues, realistic landscape visualization may actually affect behavior or policy (Sheppard 2005).

The European Landscape Conventions requires that the public be involved in decision made about the landscape. The degree of involvement for the public and different stakeholders depends on the project context, scale and objectives. Limiting participation to a one way distribution of information about landscape does not promote public trust in the planning process (Höppner et al. 2007). Rather an exchange of information (consultation) with citizens, politicians and stakeholders, such as farmers, should be a goal of effective participation. Even better is when citizens can contribute their opinions, and their concerns are reflected in the decision making process (involvement), for example about infrastructure or new housing development projects. In the case of implementation projects that go beyond the scope of landscape planning, collaborative decisions that incorporate recommendations from citizens and stakeholders represent a greater involvement of citizens in the process. Finally, democratic representation in a referendum on environmental issues represents the highest degree of participation in planning. However, the higher levels of participation hold the danger that a small group, which is not representative of the population, may dominate the decision if all groups are not fairly represented. Identifying the appropriate stakeholders and ensuring representative participation is essential to the process (Luyet et al. 2012).

In landscape planning the landowners (often the farmers) are an important stakeholder group because they are faced with the implementation of planning decisions on their land. The satisfaction of such stakeholders 
with the planning process is related to how well their participation is embedded in the planning and decision making process (Konisky \& Beierle 2001). Unfortunately, the public is often involved late in the planning process with little influence on the decisions (Conrad et al. 2011). Rather participation should be considered as early as possible and incorporated throughout the process. Furthermore, the process should represent relevant stakeholders, such as farmers, and emphasize empowerment, equity, trust and learning (Reed et al. 2009).

\section{How can visualization support participation at the landscape scale?}

Visualization tasks, effects and respective suitable techniques at the municipal decision level

In the planning context, politicians and planners must communicate information on the landscape to citizens, who perceive and understand the information in the context of their cultural and social experience (Lewis \& Sheppard 2006). A visual medium may have fewer linguistic and cultural barriers than a written or verbal message (Steinitz 2010). While traditional communication tools in planning, such as maps, diagrams, and text, remain the most common instruments for communicating information, these are limited in their ability to convey spatial understanding to lay audiences (Tress \& Tress 2003, Lewis \& Sheppard 2006). An image not only supports spatial understanding but also helps citizens to picture landscape issues and facilitates participation (Al-Kodma-

\section{Tasks of visualization in the landscape and regional planning process}

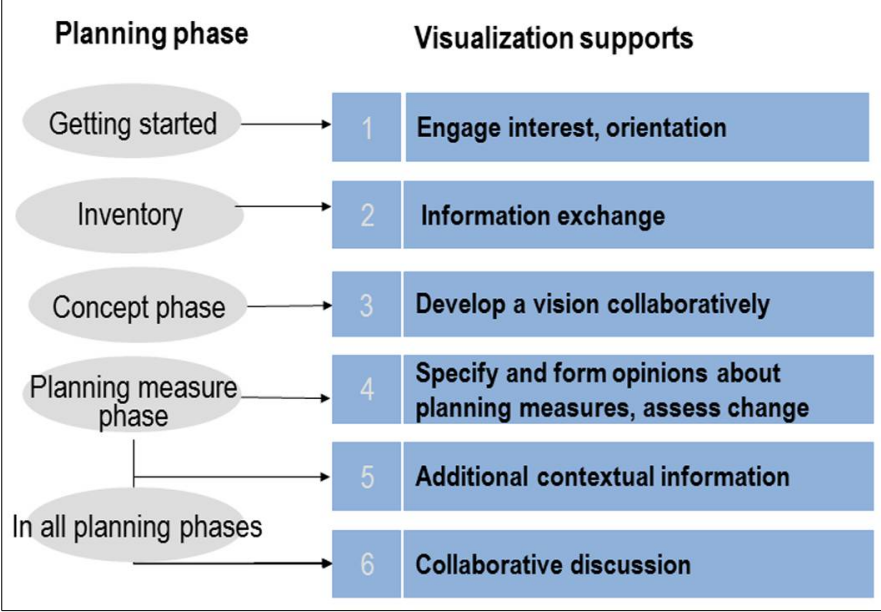
tion supports participation and communication in the different phases of landscape and regional planning. Visualization techniques tested in the IALP (von Haaren et al. 2005).

ny 1999, Langendorf 2001, Salter et al. 2009).

In landscape planning visualization supports different tasks during participation in the various planning phases (see Fig. 2). For example, a realistic, interactive visualization can trigger initial interest in the planning and spatial issues, or in the inventory and assessment phase, visualizations provide a common basis for the exchange of information and local knowledge about existing environmental data. Furthermore, stakeholders, citizens and planners can use visualizations to illustrate future scenarios and develop a "leitbild" (vision) for the landscape collaboratively. Finally, the simulation of planning measures provides a basis for discus- sing and forming opinions about the implementation of planning measures.

\section{Different types of visualization}

A wide range of visualization techniques are available offering different capabilities and possibilities to support the participatory tasks in the planning phases (Fig. 3). Among other aspects, visualization characteristics differ in dimensionality, level of realism, dynamic movement, interactivity, and display (Bishop \& Lange 2005, Warren-Kretzschmar $\&$ Tiedtke 2005). For example, two dimensional maps and aerial photographs improve the viewer's orientation in discussions. Realistic visualizations with a high degree of detail, such as photomontages or photorealistic

Fig. 3 - Visualization techniques have different characteristics - movement, realism, interactivity and dimensionality - that support different tasks in participation
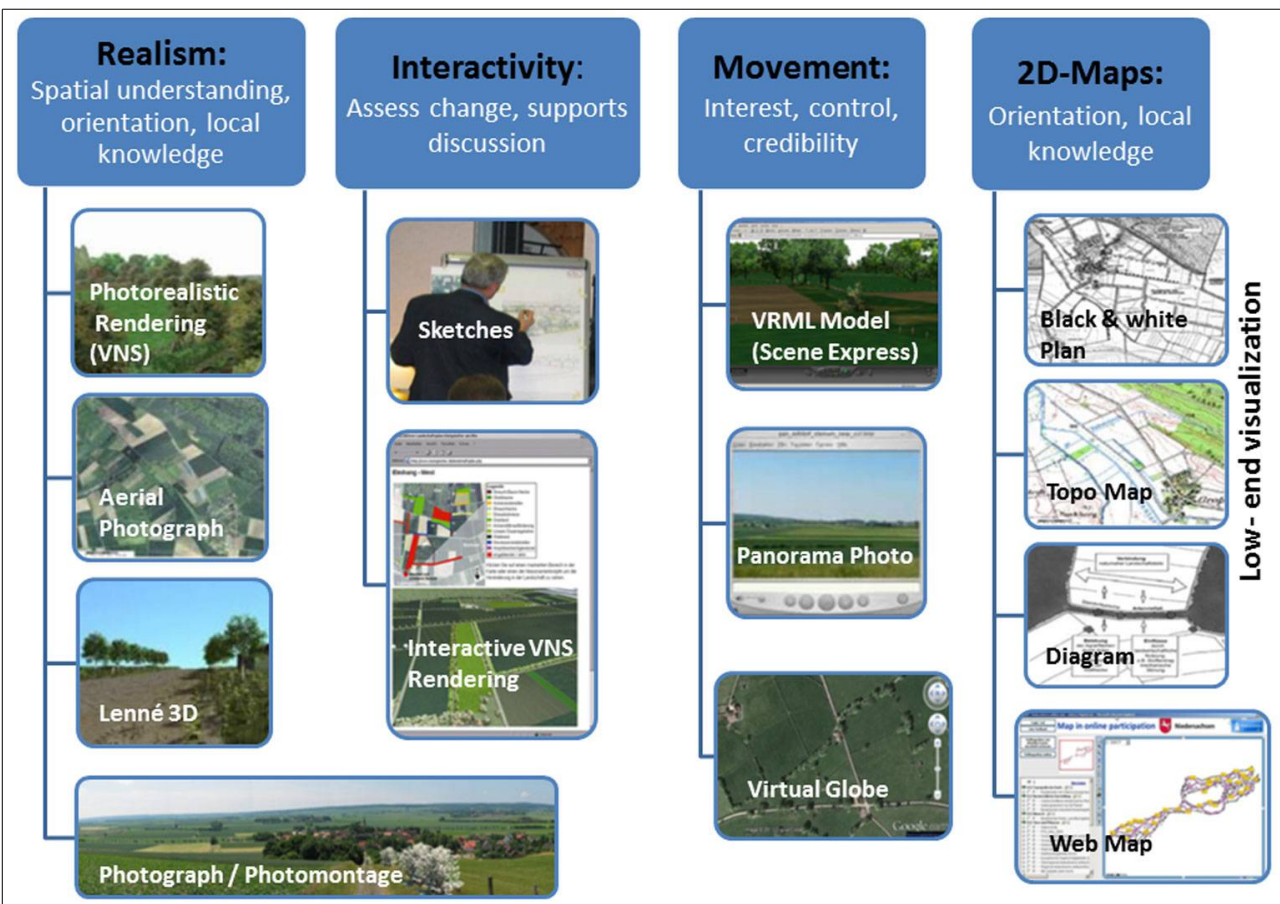


\begin{tabular}{|c|c|c|c|}
\hline \multicolumn{4}{|c|}{ Visualization characteristics and techniques in landscape planning } \\
\hline Planning phases & $\begin{array}{l}\text { Goals of } \\
\text { visualization in } \\
\text { participation } \\
\text { process }\end{array}$ & $\begin{array}{c}\text { Important } \\
\text { characteristics and effects } \\
\text { of visualization }\end{array}$ & $\begin{array}{l}\text { Potential } \\
\text { visualization } \\
\text { techniques }\end{array}$ \\
\hline Getting started & $\begin{array}{l}\text { Engage interest, } \\
\text { orientation }\end{array}$ & $\begin{array}{l}\text { Movement and realism } \rightarrow \\
\text { stimulates interest }\end{array}$ & $\begin{array}{l}\text { VR model, panorama } \\
\text { photo, virtual globe }\end{array}$ \\
\hline Inventory & Information exchange & $\begin{array}{l}\text { Realism } \rightarrow \text { spatial understanding, } \\
\text { elicits local knowledge } \\
2 \mathrm{D} \rightarrow \text { orientation, documentation }\end{array}$ & $\begin{array}{l}\text { alistic photos, GIS } \\
\text { aps, Aerial photos }\end{array}$ \\
\hline Concept phase & $\begin{array}{l}\text { Develop a vision } \\
\text { collaboratively }\end{array}$ & $\begin{array}{l}\text { Simulation of future situation / } \\
\text { compare change } \rightarrow \text { common } \\
\text { understanding }\end{array}$ & $\begin{array}{l}\text { Combine methods, } \\
\text { photorealistic vs. } \\
\text { abstract, VR models }\end{array}$ \\
\hline $\begin{array}{c}\text { Planning measure } \\
\text { phase }\end{array}$ & $\begin{array}{l}\text { Specify and form } \\
\text { opinions about } \\
\text { planning measures, } \\
\text { assess change }\end{array}$ & $\begin{array}{l}\text { Realism } \rightarrow \text { details and location } \\
\text { for collaborative discussion } \\
\text { Interactivity } \rightarrow \text { assess change }\end{array}$ & $\begin{array}{l}\text { Realistic rendering, } \\
\text { maps, VR models, } \\
\text { interactive }\end{array}$ \\
\hline $\begin{array}{l}\text { In all planning } \\
\text { phases }\end{array}$ & $\begin{array}{l}\text { Additional contextual } \\
\text { information, support } \\
\text { discussion }\end{array}$ & $\begin{array}{l}\text { Interactivity } \rightarrow \text { interest, control } \\
2 \mathrm{D} / 3 \mathrm{D} \rightarrow \text { Orientation, common } \\
\text { image as basis for discussion }\end{array}$ & $\begin{array}{l}\text { Mix of 2D and 3D } \\
\text { visualizations }\end{array}$ \\
\hline
\end{tabular}

Fig. 4 - Overview of goals, characteristics and effects of visualization that are important for selecting visualization techniques that support participation in the landscape planning process. renderings, help participants to picture the changes in the landscape. VR models, panorama photos, animations or virtual globes of fered movement through the scene, which can stimulate interest by giving the viewer control of what they see. Finally, interactive visualizations, such as sketching or geodesign options, which allow the viewer to manipulate the content of the visualization, offer great potential for collaborative discussion about planning alternatives.

Regardless of the range of possibilities, visualization must fulfill some basic requirements in order to be suitable for public participation. It must provide the participants with good orientation, spatial understanding, the ability to assess change in the landscape and credibility (Warren-Kretzschmar 2011). In other words, the visualization can support participation when the viewer understands: where $\mathrm{s} / \mathrm{he}$ is; what $\mathrm{s} / \mathrm{he}$ is viewing, which changes to the landscape are being proposed; and $s /$ he must trust that the visualization is not manipulative. Interestingly, the interactivity of the visualization plays an important role in promoting credibility of the visualization and understanding of the planning issues (Schroth et al. 2011). Participants appreciate the opportunity to interact with the information because they often want to try out their own ideas and proposals (von Haaren \& Warren-Kretzschmar 2006).

\section{Visualization requirements of the} different landscape planning phases

Which visualization method can support the participatory goals in the different planning phases depends on the characteristics and effects of the visualization methods. The findings of the IALP and recommendations for using visualizations in the different planning phases are summarized in Fig. 4 (Warren-Kretzschmar 2011)

\section{Getting started: movement and realism stimulate interest}

Movement in visualizations can capture peoples' attention and interest in the planning issues, although the initial fascination can wear off when the viewer becomes familiar with it (Schroth 2010). Realism and the viewer's perspective of the image also help viewers recognize and identify with the planning area and issues. The recognition of the personal landscape in a realistic image influences the emotional involvement of the participants (Sheppard 2005). Furthermore, the eye-level view provides the viewer with a familiar perspective that promotes identification with and interest in the landscape (Meitner et al. 2005). The findings of the IALP indicate that the panorama photo, with a rotatable, realistic, eye-level view of the landscape, is especially successful in attracting the citizens' interest and stimulating discussion about the landscape.

\section{Inventory phase: realism elicits local \\ knowledge, 2D provides orientation}

Realistic and detailed representations of the landscape are useful to verify the site inventory with stakeholders and the public. At this stage in the planning, such visualizations, e.g., aerial photos or panorama photos, not only draw out participants' local knowledge, they also give participants a sense of familia- rity and help to elicit comments about the landscape. The overview and orientation that maps and aerial photos offer help citizens to locate themselves and their knowledge in the landscape.

\section{Concept phase: simulations support common understanding}

Developing a vision or "leitbild" for the future landscape in the concept phase of planning requires a common understanding of landscape development objectives and options. The visualization must communicate ideas and concepts that are central to the landscape while recognizing the uncertainty of the future development. Although it is still unclear which approach is preferable, geo-referenced or geo-typical images have been used in visioning. Geo-referenced images show the actual site in an abstracted or stylized manner. It is contended that the visualization should be abstract or stylized because the planning ideas are not yet concrete in the concept phase. This approach suggests that schematic images such as sketches (AlKodmany 2002) or abstract versions of possible planning proposals (Coconu 2008) can be used to show spatial relationships without including specific details of the actual site.

On the other hand, the geo-typical image does not show the actual site, rather it is a realistic image or photo of a prototypical landscape. In this approach, participants can discuss potential development options using realistic images of similar planning situations on comparable sites. The realistic images give a clearer picture of how the development of different goals and objectives 
could look. However, the viewers must mentally transfer the concepts to the actual site.

\section{Planning measures: realism and interactivity help assess change}

Participants often expect the most realistic and detailed visualizations in this planning phase, so they can form qualified opinions about concrete planning measures. Although photorealistic methods help to picture the landscape change, sufficiently detailed data must be available in order to create realistic visualizations (Sheppard \& Cizek 2009). It is important to communicate the factors that limit realism to the public, so they understand the limitations of the visualization. For the participants in the IALP case study the comparison of before-and-after images also played a central role in discussions during this phase, either to explain measures, to illustrate an opinion, or even to support decisions about alternatives.

\section{Visualization in all phases - general recommendations and discussion}

The findings of the IALP case study indicate some general recommendations for using visualization in the participatory process at the landscape scale, regardless of planning phase (Warren-Kretzschmar 2007) Firstly, two dimensional visualizations remained a main stay of communication. This supports the findings of MacEachren (1994) and Arciniegas \& Janssen (2012) that 2D maps and aerial photos offer an important overview of the planning area and orientation that are important when working with citizens. Interestingly, participants with good map reading skills often prefer maps to $3 \mathrm{D}$ visualizations (Schroth 2010).

Secondly, the combination of 2D maps and $3 \mathrm{D}$ realistic still images of the landscape satisfied the participants' requirements for both orientation and spatial understanding (Warren-Kretzschmar 2011). Furthermore, a combination of methods was needed to meet the diverse needs of the participants. Although it can be debated that different visualization methods are better in different situations and for different audiences, this agrees with Appleton's findings that no single visualization method can fulfill all the wishes of the participants (Appleton et al. 2002, p. 160).

Finally, the visualizations that allowed participants to interact with the content, whether it was an artist sketching ideas or interactive 3D models, were used frequently to explain or support comments during discussions. This supports the findings of Schroth et al. (2011, p. 54), who found that when viewers can directly engage in the visualization, it promotes collaboration in a participatory planning situation. The development of new technology that makes it possible to ask "What-if?" questions of scenarios and to vi-

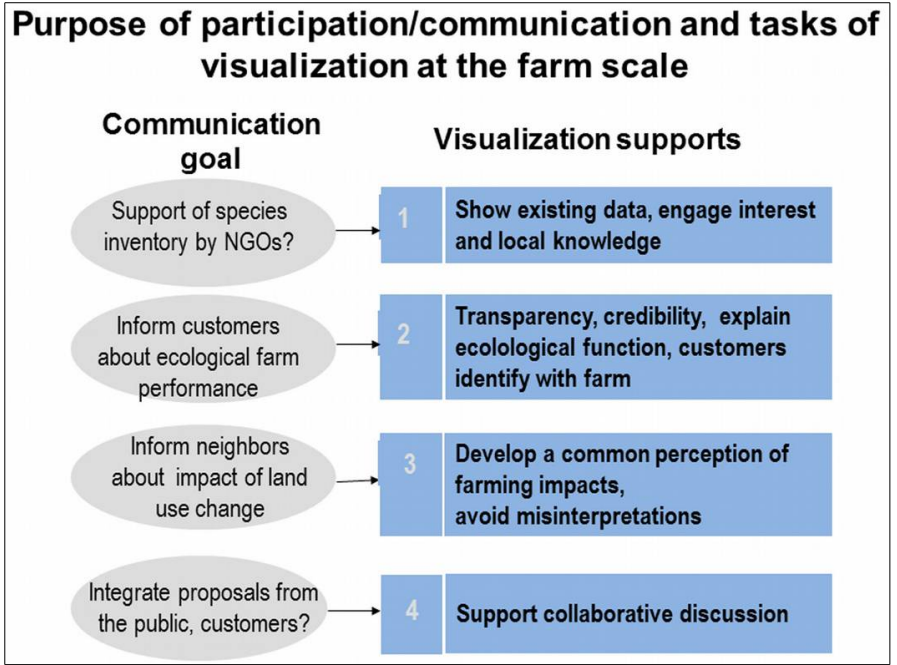

Fig. 5 - Examples of how visualization can support farmers' communication with the public, customers, food companies and authorities at the farm scale.

sualize the answers has potential to improve collaborative participation.

\section{Goals, characteristics, effects and techniques of visualization on the farms scale}

\section{Visualization goals on farm scale and present techniques}

At the landscape scale, sound environmental information and public participation in the planning process is needed to reach qualified and democratic decisions about spatial development questions. Ultimately, many of these decisions must be implemented on farms and with the support of farmers: for example, species protection, habitat networks, or the reduction of fertilizer input near areas for extraction of drinking water. Farmers need to communicate such ecosystem services to the public in order to improve acceptance and recognition for their contributions, for example, in the local community. In addition, customers of farm products want to know about the environmental performance of farms or the life cycle of the products. Authorities require information about the ecological results of payments for ecosystem services, for example, in agri-environmental measures (von Haaren et al. 2012). Furthermore, when farmers make changes in agricultural land use it changes the landscape that neighbors and the local community see and experience. Therefore they must communicate the reasons for change, and when possible, allow the public to be part of the decisions about changes that directly affect them. In fact, a farmer's good "image" depends on the visual quality of the landscape, nature conservation achievements on the farm and the openness of farmers to communicate.

The necessity of good communication at the farm scale is evident in the numerous examples of citizens protesting against the increase of energy crops or the siting of wind mills or the construction of buildings for livestock. The goal of visualization at the farm scale is to communicate changes in the landscape that result from farming practices and agri-environmental measures to perspective customers and interested parties. Using two and three dimensional visualizations, farmers can help local citizens understand landscape changes occurring on their farms (e.g., effect of crops such as maize or short rotation coppice). In this way, farmers can increase the acceptability of the changes or even integrate citizens' proposals into planned land use changes (see Fig. 5).

\section{Requirements for visualization}

characteristics and desired effects at the farm scale and proposed visualization techniques

Based on the experience gained in the IALP case study, we deduced recommendations for the use of visualization at the farm scale. Our analysis indicates that visualizations fulfill similar communication objectives on the farm scale as they do on the municipal level (Fig. 5). Also at the farm scale visualization must also fulfill the prerequisites of good orientation, spatial understanding, ability to assess change and credibility. The findings indicate that $2 \mathrm{D}$ visualizations with maps and charts can satisfactorily communicate non-visual or conceptual information to the farm customers, neighbors and local community. For example, invisible or temporal landscape processes at the farm scale, e.g., good farming practice to reduce nitrate in the ground water or measures to improve biotope connectivity, can be illustrated in maps with additional information in the form of charts and graphs. Being able to view the data and compare the evaluation of biodiversity, soil and landscape aesthetics can support transparency and trust in the farm products. Also scenarios of farm management visualized in maps can help communicate changes to affected parties. According 


\begin{tabular}{|c|c|c|c|}
\hline \multicolumn{4}{|c|}{ Visualization goals, characteristics and techniques at the farm scale } \\
\hline $\begin{array}{c}\text { Participation/ } \\
\text { Communicationgoal }\end{array}$ & $\begin{array}{l}\text { Goals of } \\
\text { visualization in } \\
\text { participation } \\
\text { process }\end{array}$ & $\begin{array}{l}\text { Important } \\
\text { characteristics and } \\
\text { effects of visualization }\end{array}$ & $\begin{array}{l}\text { Potential } \\
\text { visualization } \\
\text { techniques }\end{array}$ \\
\hline $\begin{array}{l}\text { Support of species } \\
\text { inventory by NGOs? }\end{array}$ & $\begin{array}{l}\text { Show existing data, } \\
\text { engage interest and } \\
\text { local knowledge }\end{array}$ & $\begin{array}{l}\text { Realism } \rightarrow \text { recognition, detail } \\
2 \mathrm{D} \rightarrow \text { orientation } \\
\text { Interactivity } \rightarrow \text { interest, } \\
\text { control }\end{array}$ & $\begin{array}{l}\text { Maps, aerial } \\
\text { photos, photos of } \\
\text { biotopes and } \\
\text { species, charts }\end{array}$ \\
\hline $\begin{array}{c}\text { Inform customers } \\
\text { about ecological farm } \\
\text { performance }\end{array}$ & $\begin{array}{l}\text { Transparency, } \\
\text { credibility, explain } \\
\text { ecol. function, } \\
\text { customers identify } \\
\text { with farm } \\
\end{array}$ & $\begin{array}{l}\text { Realism } \rightarrow \text { spatial } \\
\text { understanding, visual quality } \\
\text { Interactive } \rightarrow \text { explain } \\
\text { changes, interest }\end{array}$ & $\begin{array}{l}\text { Maps, aerial } \\
\text { photos, diagrams, } \\
\text { panorama photos }\end{array}$ \\
\hline $\begin{array}{c}\text { Inform neighbors } \\
\text { about impact of land use } \\
\text { change }\end{array}$ & $\begin{array}{l}\text { Develop common } \\
\text { perception of } \\
\text { farming impacts, } \\
\text { avoid } \\
\text { misinterpretations }\end{array}$ & $\begin{array}{l}\text { Realism } \rightarrow \text { Assess visual } \\
\text { quality, spatial understanding } \\
2 \mathrm{D} \rightarrow \text { orientation } \\
\text { Movement } \rightarrow \text { control view }\end{array}$ & $\begin{array}{l}\text { Photorealistic } \\
\text { renderings (VNS), } \\
\text { maps, 3D VR } \\
\text { models, charts }\end{array}$ \\
\hline $\begin{array}{l}\text { Integrate proposals from } \\
\text { the public, customers? }\end{array}$ & $\begin{array}{l}\text { Support } \\
\text { collaborative } \\
\text { discussion }\end{array}$ & $\begin{array}{l}2 \mathrm{D} \rightarrow \text { orientation, locate } \\
\text { suggestions } \\
\text { Realism } \rightarrow \text { shared image } \\
\text { Interactivity } \rightarrow \text { assess } \\
\text { change }\end{array}$ & $\begin{array}{l}\text { Photorealistic } \\
\text { renderings, 3D } \\
\text { models, } \\
\text { interactive maps }\end{array}$ \\
\hline
\end{tabular}

to the findings on the landscape level, maps and charts can suffice for these purposes. Fig. 6 shows potential visualization goals at the farm level and the characteristics and effects of visualization that are required to fulfill these goals.

However, if the general public should understand and accept visual changes occurring on the farm, then they will need more than two dimensional visualization methods. 3D visualization techniques are needed to show a perspective view of the landscape that can portray proposed development in a realistic context. Research suggests that realistic, 3D visualizations increase understanding and help people relate to the landscape changes (Sheppard 2012). Farmers could use real-time, 3D visualizations not only to attract customers but also to promote an understanding of the ESS they provide to the public.

\section{Supporting visualization with farm} management data

We tested the feasibility of different visualization options with respect to available data and EDV support in the farm management
Fig. 6 - Recommendations for the integration of visualization on the farm scale.

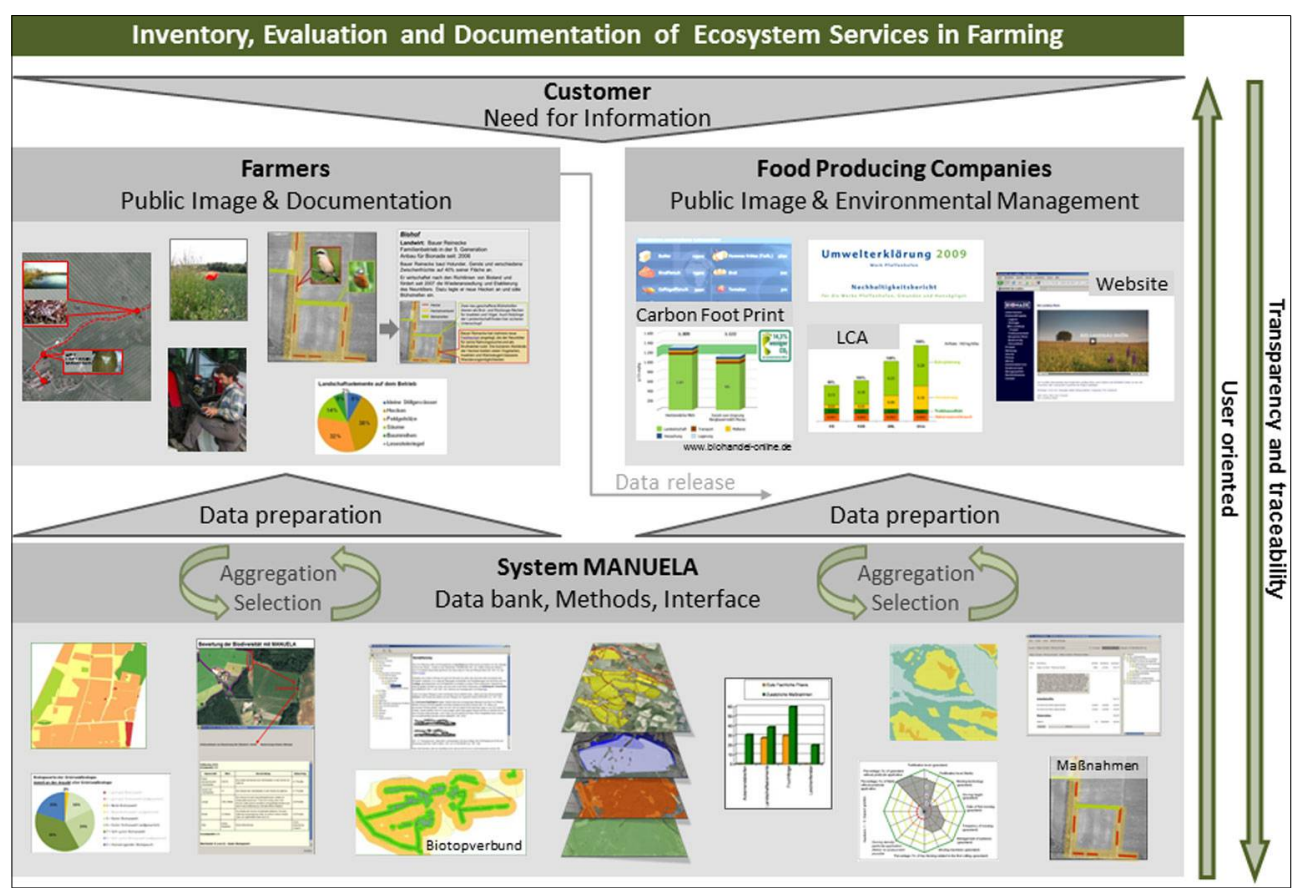

system (MANUELA). MANUELA is a computer system that assists farmers with the management of agri-environmental measures and sustainable farm practices on individual farms (von Haaren et al. 2012). It can be used not only to document but also to market the farm's ecosystem services (ESS) to contracting food producers as well as local customers. Using the open source GIS program OpenJUMP ${ }^{\circledR}$ (http://www.openjump.org/), the system supports the inventory, assessment, documentation, planning and cost calculations of ESS that a farm offers. MA-
Fig. 7 - Overview of the visualization functions of MANUELA (source: Kempa 2012) 


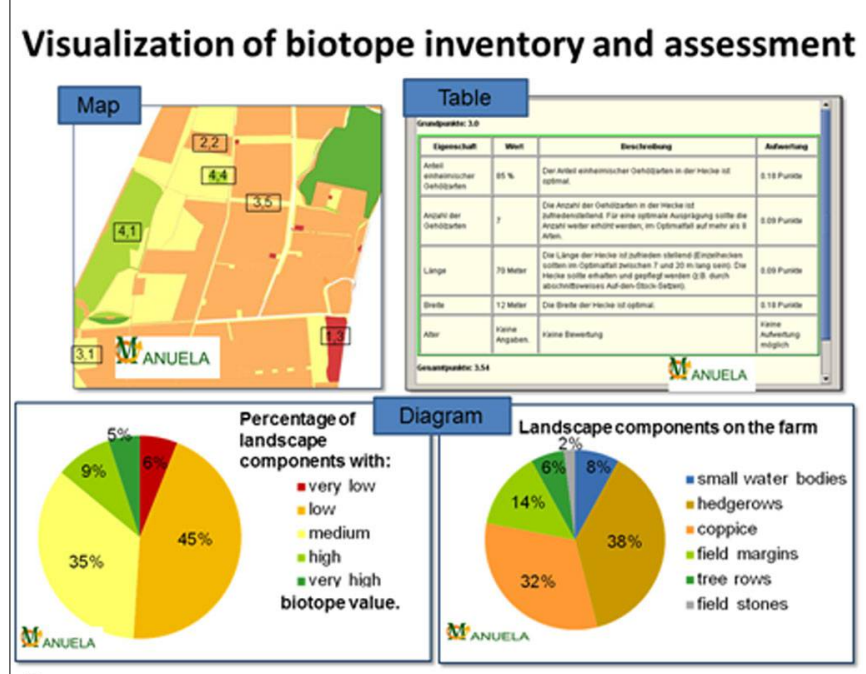

$8 \mathrm{a}$
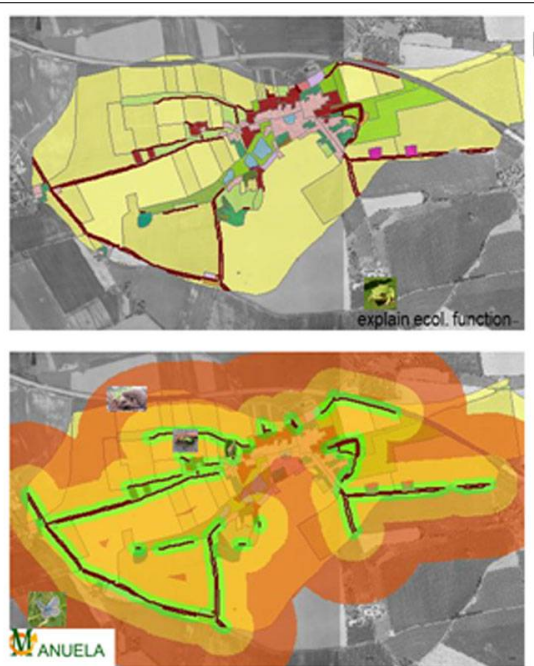

$8 b$
Biotope connectivity

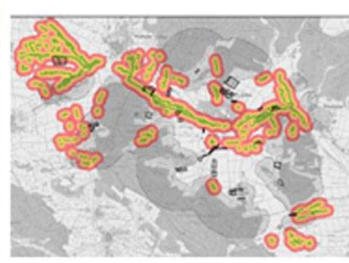

Biotope connectivity for species of a grove/bosque

Distance can be covered by:

all species

most species

some species

only few species

3. 203

Fig. 8 - (a) Visualization of biotope inventory. (b) Visualization of biotope connectivity in MANUELA. Data about ESS can be visualized with maps, diagrams, tables and photos. Presenting the data supports transparency of decisions about ESS.

NUELA also provides spatial analysis and evaluation of management decisions. Fig. 7 gives an overview of the different components and capabilities of MANUELA.

Presently, visualizations implemented in MANUELA consist mainly of GIS maps and charts drawn from data about the individual farms. This information and corresponding still images are used to illustrate the changes in the ecosystem services. For example, the data about the biotope inventory is illustrated in maps and tables and the assessment can be visualized in diagrams (see Fig. 8a and Fig. $8 \mathrm{~b}$ ).

However, the potential of the farm management system MANUELA to support more sophisticated visualizations is excellent. The GIS data used in MANUELA is comparable to or even more detailed than the data used at the landscape level in the Interactive Landscape Plan. Therefore, more sophisticated visualization techniques could be created to illustrate landscape change at the farm level. For example, an elevation model, which is a prerequisite for $3 \mathrm{D}$ visualizations, is a standard feature for soil erosion assessment. Furthermore, the habitat data at the farm level in MANUELA is far more detailed than at the landscape level. This fulfills many of the prerequisites for creating realistic and detail landscape visualizations equally well, if not better than at the landscape level. The same is true for data about cultivated crops and their phenology over the course of the year, which enables the visualization of temporal changes of the landscape.

If the software from the interactive landscape planning tool box was used to create visualizations with this excellent data basis, the results could satisfy all the information and communication requirements of the various addressees. For example, interactive maps and $3 \mathrm{D}$ visualizations could be used to communicate major landscape changes planned by the farmer. A real-time 3D model could allow customers to take a virtual stroll through the farm. Interactive maps could enable local citizens to interactively contribute data about species that they have sighted (crowd sourcing). However, such visualization methods require expertise that farmers do not generally have and the software is often expensive. Until the technology becomes easier to use, creative ways to integrate simpler solutions, such as photos or videos on YouTube ${ }^{\circledR}$, may have to suffice. Nevertheless, the potential of interactive visualizations to attract attention to the highlights of a farm should not be ignored, even if they must be produced by an expert. A flyover animation or a video that offers a virtual hike through the farm may be an effective advertisement.

\section{Discussion of farm scale visualization}

Farmers can make their achievements more public by visualizing the environmental improvements on their farm. At the same time, such visualizations can be used to manage and document the performance of ESS produced by the farm. However, the farm scale visualization is place-based, in other words it addresses decisions made for one farm. The surrounding landscape can be only partially represented, which does not provide a visual overview of the contextual landscape. For example, the cumulative effect of several farmers cultivating energy crops on the wider landscape is not illustrated. The same applies to representing the connectivity of larger ecological systems that span multiple farms. Such issues need to be addressed at the landscape scale, and the visualizations must be able to bridge the farm and landscapes scale in order to show the effects of farm decisions on both the farm and landscape scales.

A common perception about the impacts of farm measures is crucial in order to avoid misinterpretations and misunderstandings about changes in the landscape at the farm scale. Presently such changes are generally visualized with maps and diagrams. However, visual impacts are best understood with realistic simulations or real time models that require expert know-how or specialized visualization techniques. Until these technologies become easier to use, farmers must depend on simple "crutches", such as "before and after" photos or videos. Therefore, developing easy to use $3 \mathrm{D}$ and interactive visualization techniques that can simulate landscape changes is an urgent request for the future.

\section{Conclusions}

In order to use visualization in a targeted and efficient way, it is important to analyze the application objectives as well as the respective visualization tasks and intended effects. This analysis, both on the landscape as well as on farm scale, is a prerequisite for choosing a suitable visualization technique. At all scales visualizations must provide good orientation, spatial understanding, the ability to assess change and credibility.

At the landscape scale, visualizations can support participation in the:

- early phases of planning by stimulating interest with realistic or moving images; 
- inventory phase by providing realistic visualizations of the existing landscape that help participants to contribute local knowledge;

- concept phase by supporting discussion about a "leitbild" concept for the landscape with either geo-typical or geo-referenced images;

- final planning phases by illustrating planning measures with realistic visualization methods that offer different views of the planning.

At the landscape scale, the findings indicate that two dimensional maps and aerial photographs provide participants with the necessary overview and orientation. In combination with three dimensional, realistic visualizations, they form a good basis for discussing landscape issues. Furthermore, interactive visualizations promote collaborative discussion as well as credibility in the participatory process. New technologies that allow participants to pose questions and interact with the visualized information offer potential to make participation in the planning process more collaborative. However, a combination of different visualization methods is needed in order to meet the diverse requirements of the participants and the participatory goals.

Visualizations not only improve the involvement of citizens and stakeholders in the planning process at the landscape level, they also provide transparency at the farm scale. At farm scale, visualizations can be used to communicate visual landscape changes that result from altered agricultural practices and the development of farm infrastructure. They can also communicate information to customers (food companies, tourists, customers of farm sale, neighbors) about the ESS that farmers produce by showing where and how the actual measures are implemented.

Presently, maps and diagrams of ecosystem services that are generated from GIS data can be visualized and made public on the web by farm management systems like in MANUELA. This in combination with simple visualizations such as photos may be sufficient to present many of the issues at the farm scale. However, $3 \mathrm{D}$ visualizations illustrate visual changes in the landscape more effectively. For this, farmers and farm advisers need easy to use 3D visualization technologies that do not yet exist. The development of user-friendly 3D visualization methods, preferably open source, is essential to help farmers simulate visual landscape change on their farms.

Further research should address the interrelationship of effective visualization on both the landscape and farms scale. Possibly, visualizations at both scales may improve the decisions at the landscape level by making the consequences at the farm level clearer. Conversely, the visualization of ESS at the farm scale may improve farmers "bargaining power" in landscape decisions.

\section{References}

Al-Kodmany K (1999). Using Visualization Techniques for Enhancing Public Participation in Planning and Design: Process, Participation, and Evaluation. Landscape and Urban Planning 45 (1): 37-45. - doi: 10.1016/S0169-2046(99)00024 $-9$

Al-Kodmany K (2002). Visualization Tools and Methods in Community Planning: From Freehand Sketches to Virtual Reality. Journal of Planning Literature 17 (2): 189-211. - doi: 10.11 77/088541202762475946

Appleton K, Lovett A, Sünnenberg G, Dockerty T (2002). Rural landscape visualization from GIS databases: A comparison of approaches, options and problems. Computers, Environment and Urban Systems 26: 141-162. - doi: 10.1016/S01 98-9715(01)00041-2

Arciniegas G, Janssen R (2012). Spatial decision support for collaborative land use planning workshops. Landscape and Urban Planning 107 (3): 332-342. - doi: 10.1016/j.landurbplan.2012. 06.004

Arnstein S (1969). A ladder of citizen participation. Journal of the Royal Town Planning Institute 35 (4): 216-224. [online] URL: http://lith gow-schmidt.dk/sherry-arnstein/ladder-of-citizen -participation en.pdf

Bailey K, Grossardt T (2009). Toward structured public involvement: justice, geography and collaborative geospatial/geovisual decision support systems. Annals of the Association of American Geographers 100 (1): 57-86. - doi: 10.1080/0004 5600903364259

Bishop ID, Lange E (2005). Visualization in landscape and environmental planning. Technology and applications. Taylor \& Francis, London, UK and New York, USA. [online] URL: http://books.google.it/books?id=HDp5AgAAQBAJ

Coconu L (2008). Enhanced visualization of landscapes and environmental data with three-dimensional sketches. $\mathrm{PhD}$ thesis, Universität Konstanz, Switzerland, pp. 107.

Conrad E, Cassar L, Jone, M, Eiter S, Izaovicova Z, Barankova Z, Christie M, Fazey I (2011). Rheotoric and Reporting of Public Participation in Landscape Policy. Journal of Environmental Policy and Planning 13 (1): 23-47. - doi: 10.108 0/1523908X.2011.560449

DiBiase D, MacEachren AM, Krygier JB, Reeves $C$ (1992). Animation and the role of map design in scientific visualization. Cartography and Geographic Information Science 19 (4): 201-214. doi: $10.1559 / 152304092783721295$

Höppner C, Frick J, Buchecker M (2007). Assessing psycho-social effects of participatory landscape planning. Landscape and Urban Planning 83 (2-3): 196-207. - doi: 10.1016/j.landurbplan. 2007.04.005

IAP2 (2004). IAP2 public participation spectrum. International Association for Public Partecipation, Wollongong, New South Wales, Australia, pp. 1. [online] URL: http://www.iap2.org.au/ documents/item $/ 84$

Kempa D (2012). Bedingungen für den Einsatz einer Software für Naturschutzberatung und -dokumentation auf landwirtschaftlichen $\mathrm{Be}$ trieben [Requirements for the use of software in nature conservation planning and documentation on farms]. PhD thesis, Institute for Environmental Planning, Leibniz University Hannover, Germany, pp. 65. [in German]

Konisky DM, Beierle TC (2001). Innovations in public participation and environmental decision making. Examples from the Great Lakes region. Society and Natural Resources 14: 815-826. doi: 10.1080/089419201753210620

Lange E (2001). The limits of realism: perceptions of virtual landscapes. Landscape Urban Planning 54: 163-182. - doi: 10.1016/S0169-2046(01)001 34-7

Langendorf R (2001). Computer-aided visualization: possibilities for urban design, planning, and management. In: "Planning Support Systems: Integrating Geographic Information Systems, Models, and Visualization Tools" (Brail RK, Klosterman RE eds). ESRI Press, Redlands, CA, pp. 309-359.

Lewis JL, Sheppard SRJ (2006). Culture and communication: can landscape visualization improve forest management consultation with indigenous communities? Landscape and Urban Planning 77 (3): 291-313. - doi: 10.1016/j.landurbplan.2005. 04.004

Luyet V, Schlaepfer R, Parlange MB, Buttler A (2012). A framework to implement stakeholder participation in environmental projects. Journal of Environmental Management 111: 213-219. doi: 10.1016/j.jenvman.2012.06.026

MacEachren A (1994). Some truths with maps: a primer on symbolization and design. Association of American Geographers, Washington, DC, USA, pp. 129.

Meitner MJ, Sheppard SRJ, Cavens D, Gandy R, Picard P, Harshaw H, Harrison D (2005). The multiple roles of environmental data visualisation in evaluating alternative forest management strategies. Computers and Electronics in Agriculture 49: 192-205. - doi: 10.1016/j.compag.2005. 03.002

Nicholson-Cole SA (2005). Representing climate change futures: a critique on the use of images for visual communication. Computers, Environment and Urban Systems 29: 255-273. - doi: 10.1016/j.compenvurbsys.2004.05.002

Pettit C, Bishop I, Sposito V, Aurambout JP, Sheth F (2012). Developing a multi-scale visualisation framework for use in climate change response. Landscape Ecology 27: 487-508. - doi: 10.1007/s10980-012-9716-5

Reed MS (2008). Stakeholder participation for environmental management: a literature review. Biological Conservation 141 (10): 2417-2431. doi: 10.1016/j.biocon.2008.07.014

Reed MS, Graves A, Dandy N, Posthumus H, Hubacek K, Morris J (2009). Who's in and why? A typology of stakeholder analysis methods for natural resource management. Journal of Environmental Management 90 (5): 1933-1949. - doi: 
10.1016/j.jenvman.2009.01.001

Salter JD, Campbell C, Journeay M, Sheppard SRJ (2009). The digital workshop: exploring the use of interactive and immersive visualisation tools in participatory planning. Journal of Environmental Management 90: 2090-2101. - doi: 10.1016/j.jenvman.2007.08.023

Schroth O (2010). From information to participation. Interactive landscape visualization as a tool for collaborative planning. University Press, Swiss Federal Institute of Technology, Zurich, Switzerland, pp. 224.

Schroth O, Wissen U, Schmid WA (2006). Developing new images of rurality: interactive $3 \mathrm{D}$ visualisations for participative landscape planning workshops in the Entlebuch UNESCO biosphere reserve. disP - The Planning Review 42 (166): 26-34. - doi: 10.1080/02513625.2006.105 56960 Schroth O, Hayek UW, Lange E, Sheppard SRJ, Schmid WA (2011). Multiple-case study of landscape visualizations as a tool in transdisciplinary planning workshops. Landscape Journal 30 (1): 53-71. - doi: 10.3368/lj.30.1.53

Shaw A, Sheppard S, Burch S, Flanders D, Wiek A, Carmichael J, Robinson J, Cohen S (2009). Making local futures tangible'Synthesizing, downscaling, and visualizing climate change scenarios for participatory capacity building. Global Environmental Change 19 (4): 447-463. doi: 10.1016/j.gloenvcha.2009.04.002

Sheppard SRJ, Cizek P (2009). The ethics of Google Earth: crossing thresholds from spatial data to landscape visualisation. Collaborative GIS for spatial decision support and visualization. Journal of Environmental Management 90 (6): 2102-2117. - doi: 10.1016/j.jenvman.2007. 09.012

Sheppard SR (2001). Guidance for crystal ball gazers: developing a code of ethics for landscape visualization. Landscape and Urban Planning 54
(1-4): 183-199. - doi: 10.1016/S0169-2046(01) 00135-9

Sheppard SRJ (2005). Landscape visualisation and climate change: the potential for influencing perceptions and behavior. Mitigation and adaptation strategies for climate change. Environmental Science and Policy 8 (6): 637-654. - doi: 10.1016/j.envsci.2005.08.002

Sheppard SRJ (2012). Visualizing climate change - a guide to visual communication of climate change and developing local solutions. Routledge, London, UK, pp 511.

Soliva R, Hunziker M (2009). Beyond the visual dimension: using ideal type narratives to analyse people's assessments of landscape scenarios. Land Use Policy 26: 284-294. - doi: 10.1016/ j.landusepol.2008.03.007

Steinitz C (2010). Landscape architecture into the $21^{\text {st }}$ century - methods for digital techniques. In: "Digital Landscape Architecture 2010" (Buhmann E, Pietsch M, Kretzler E eds). Wichmann Verlag, VDE Verlag GmbH, Berlin and Offenbach, Germany, pp. 2-26.

Tress B, Tress G (2003). Scenario visualisation for participatory landscape planning'a study from Denmark. Landscape and Urban Planning 64 (3): 161-178. - doi: 10.1016/S0169-2046(02) 00219-0

von Haaren C, Warren-Kretzschmar B (2006). The interactive landscape plan: use and benefits of new technologies in landscape planning and discussion of the interactive landscape plan in Koenigslutter am Elm, Germany. Landscape Research 31:83-105 - doi: 10.1080/014263905004 48625

von Haaren C, Oppermann B, Friese KI, Hachmann R, Meiforth J, Neumann A, Tiedtke S, Warren-Kretzschmar B, Wolter FE (2005). Interaktiver Landschaftsplan Königslutter am Elm [Interactive landscape plan Koenigslutter am
Elm]. Naturschutz und Biologische Vielfalt 24, Bonn Bad Godesberg, Germany, pp. 269. [in German]

von Haaren C, Kempa D, Vogel K, Rüter S (2012). Assessing biodiversity on the farm scale as basis for ecosystem service payments. Journal of Environmental Management 113: 40-50. doi: 10.1016/j.jenvman.2012.07.033

Warren-Kretzschmar B, Tiedtke S (2005). What role does visualization play in communication with citizens? A field study from the interactive landscape plan. In: "Trends in Real-Time Landscape Visualization and Participation" (Buhmann E, Paar P, Bishop ID, Lange E eds). Herbert Wichmann Verlag, Heidelberg, Germany, pp. 156-167.

Warren-Kretzschmar B (2007). Visualisierungen in der interaktiven Landschaftsplanung einsetzen: Spektrum der technischen Möglichkeiten und Anwendungesbeispiele [Using visualization in landscape planning: spectrum of technical opportunities and examples]. In: "Leitfäden zur interacktiven Landscaftsplanung [Guidelines for Interactive Planning]". Bundesamt für Naturschutz, Bonn - Bad Godesberg, Germany, pp. 32. [in German]

Warren-Kretzschmar B (2011). Visualization in landscape planning: choosing appropriate visualzation methods for public participation. PhD Thesis, Architektur und Landschaft, Leibniz Universität Hannover, Germany, pp. 293. [online] URL: http://edok01.tib.uni-hannover.de/ edoks/e01dh11/672472341.pdf

Wiedemann I, Femers S (1993). Public participation in waste management decision making: analysis and management of conflicts. Journal of Hazardous Materials 33 (3): 355-368. - doi: 10.1016/0304-3894(93)85085-S 